\title{
1 The making and circulation of Nordic models
}

\section{An introduction}

\author{
Haldor Byrkjeflot, Mads Mordhorst and \\ Klaus Petersen
}

Since the early twentieth century, Nordic societies have attracted the attention of international observers. From this attention grew the concept of a 'Nordic model', still today a dominant idea among academics as well as policymakers, experts, social movements and the like. For most people, 'the Nordic Model' represents a progressive pathway successfully combining factors such as economic growth, democracy, social and gender equality, social welfare, a highly skilled labor force, and high quality of living. However, for others, more critically minded, the Nordic model represents paternalistic, self-righteous, homogenous - quasi-socialist - welfare states which tax their citizens far too much and represent xenophobic treatment of asylum seekers and non-Western ethnic groups. In other words, we do not only find positive views of 'Nordic solutions'; there are also very strong negative images as well.

This does not only reflect the diverging ideological frames or political positions of the observers; it also reflects the movement toward multiple understandings of the Nordic model. Although mainly associated with developments in the sphere of socioeconomics, labor, and welfare (Christiansen et al., 2006; Dølvik et al., 2015), the Nordic model has expanded into labeling a diversity of experiences and perspectives in spheres like gender equality, education, daycare, prisons, design, food, and culture. The idea of Nordic models has thus traveled into new fields of expertise, culture, institutional spheres, or lifestyles, but there is a lack of knowledge on how this has happened and how the models in the different fields are related.

Drawing on theories of translation, cross-national policy transfer, diffusion theory, and transnational history, this volume emphasizes how ideas related to the Nordics as models and policies associated with them have circulated internationally. By circulation we mean 'a double movement of going back and forth and coming back, which can be repeated indefinitely' (Markovits et al., 2006: 2-3, see also Marklund and Petersen, 2013). This way, our circulation approach differs from the more one-directional translation perspective which focuses on the travel of ideas from source to receiver but shares the assumption that ideas and models get transformed during their journey. 


\section{Haldor Byrkjeflot et al.}

Historians have pointed out that knowledge related to Nordic exceptionalism, in its many manifestations, is a cultural construction (Sørensen and Stråth, 1997). This perspective does not reject the importance of institutional similarities or other kinds of common Nordic traits (or the opposite), but it emphasizes that our understandings and conceptualizations of such similarities and differences have been culturally constructed - and these constructions have real-life repercussions. The way we label 'the Nordic Model' matters. In this volume, we go beyond the Nordic realm and demonstrate how international circulation has informed the analysis of the Nordic trajectory as well as how the Nordic societies were socially constructed as models. Meanings, content, and values associated with Nordic models both historically and in the present may be related to their history of circulation (see also Petersen, 2011; Kettunen et al., 2016).

Rather than seeing a Nordic model as a something defined once and for all, we argue that it may be seen as what in conceptual history is called a 'collective singular' (Koselleck, 2011: 13), a concept that is mentioned in singular, but in praxis is used in different ways in space and over time. How this exactly happens is an empirical question addressed in this volume. These ways of using 'the Nordic Model' allow for exploration of the many historical layers that underpins it, which again opens for understanding the possible coexistence of different meanings activated at the same time. On the one hand, there are meanings on a synthetic level, claims about common traits in the five countries across more than one issue area (Chapter 3). On the other hand, there are also a set of meanings associated with specific issue areas or spheres, such as the Nordic model of healthcare policy (Chapter 11), prostitution regulation (Chapter 9), or New Nordic cuisine (Chapter 12). The aim of this book is to pay attention to the historical multitude of circulating ideas referred to as 'Nordic' at the general level, associated with the specific Nordic countries (Denmark, Finland, Iceland, Norway, Sweden) and linked to various fields.

The historical layers and dualities of the Swedish and Nordic models are discussed in more detail in the chapters by Kettunen and Petersen (Chapter 2) and Mjøset (Chapter 3). Kettunen and Petersen refer to the way there is both a nostalgia and a future-oriented aspect associated with the use of the model. First, there is the idea of a people's home that may provide a shelter from international competition, whereas the more future-oriented aspect of the model suggests that we all have to adapt to global markets in order to stay competitive (see also Chapter 4). Mjøset refers to three versions of the Swedish model: the radical, the cautious, and the liberal/conservative model. The first two models circulated in the mid-1970s in Sweden, while the liberal/conservative model has become more important over time. Currently the neoliberal Nordic model may again be challenged as the COVID pandemic has favored ideas of a strong public sector and state intervention, which may result in a return to previous perceptions of the Nordic models or to something new. The most important insight here, however, is that such 
ambivalent images of the Nordic model contribute to its circulation as it may be - or at least sound - attractive to a diverse set of audiences and carriers of ideas at the same time.

\section{Approaches to the Nordic model}

As demonstrated by comparative research (Esping-Andersen, 1990) and aggregated analyzes of indexes (Kirkebø et al., 2021), the Nordic countries often cluster, differing from other nation states and 'families of nations' (Castles, 1993) on multiple dimensions. Arguably, the most established feature is the Nordic welfare model with comprehensive and generous welfare states (Esping-Andersen, 1990; Christiansen et al., 2006). However, scholars have also highlighted other aspects related to particular institutionalized spheres of these societies such as gender equality (Hernes, 1987; Lundqvist, 2017), labor market relations (Hvid and Falkum, 2018), old age pensions (Petersen and Åmark, 2006), the role of experts and knowledge (Lundqvist and Petersen, 2010; Christensen et al., 2017; Österling et al., 2020), politics (Nedergaard and Wivel, 2017), industrial management (Byrkjeflot et al., 2001), and education (Blossing et al., 2014). This list can be expanded to include other perspectives such as Lutheranism (Markkola, 2015; Nelson, 2017), the role of Social Democracy (Brandal et al., 2013), Nordic democracy and political culture (Knutsen, 2017), Nordic cooperation (Strang, 2016; Mordhorst and Jensen, 2019), Nordic capitalism (Byrkjeflot et al., 2001; Fellman et al., 2008; Mjøset, 2011), and Nordic civil society (Stenius, 2010).

More recently, literature on the Nordic model has expanded beyond the academic (and political) market (discussed in Chapters 5-11) and ventured into the general popular life-style literature. In some ways, popular books on the Nordic model are not anything new, and the Nordic countries have for almost a century used the Nordic model brand as a selling point for products (see Chapters 12 and 13) and tourism (see Chapter 4). However, the post-2000s Nordic hype has engaged new topics such as popular culture, food, and comfort. Concepts like happiness, Nordic cuisine, and 'hygge' (Wiking, 2016) are associated with a Nordic way of living. Likewise, cultural innovations of New Nordic cuisine, Nordic design, Nordic Noir, and Nordic music have similarly become brands that are sold as products.

In this way, studies on the Nordic model - or rather the Nordic models (in plural) - have demonstrated its multiple societal and cultural dimensions. We want to add to and challenge the existent literature in four ways:

First, we add a historical and sociological dimension highlighting the dynamic character of the Nordic model. The term Nordic 'model' was popularized in the 1980s (see Chapter 4) although as many of the chapters in this book show Nordic societies and policies were already 'modelized' throughout the twentieth century. Over time, the content, the images, and the valorization of the Nordic model have changed significantly. We need to approach 
the Nordic model as something historically dynamic where meanings and connotations change over time.

Second, we add a transnational dimension. The Nordic model was not the result of splendid Nordic isolation, but of national Nordic processes constantly interacting with the outside world. Following the Finnish historian Pauli Kettunen (2011), comparison is not only an analytical strategy used by researchers but also a part and parcel of policymaking. National policy processes are based on cross-country learning and diffusion (cf. Rose, 1991), and political debates are loaded with comparisons. As pointed out by von Beyme (1994), the use of models is often serving domestic political purposes rather than aiming for a true representation of the model's origin in a scientific empirical sense. In this way, the image of Nordic societies in US or Chinese debates should not be expected to offer a 'correct' representation of Nordic social reality (see Chapters 5-8). However, when such images of a model - positive or negative, true or false - become part of the circulation of the 'model,' they might even have significant feedback and impact in its geographical origin. (This is demonstrated in several chapters, but see especially Chapters 5, 7, 9, 10, and 13 for this.)

Third, we add a political dimension by asking to what extent the discourse around the Nordic model has been part of domestic power struggles within the Nordic region. Chapters 5 and 6 show how the Swedish prime minister, Olof Palme, first rejected the suggested reference to Sweden as a model by journalists and politicians, but that he later appropriated the idea of a Swedish/Nordic model as a response to the challenge from the right of the political spectrum during the election campaign in 1976. Furthermore, as pointed out in Chapter 3, the Nordic social democrats adopted the Nordic model concept in the early 1980s as part of discussions in SAMAK, the discussion forum for Nordic social democratic parties and unions (see also Lundberg, 2006). Finally, the idea of a 'Nordic model' was again politicized as the Swedish moderate-liberal coalition government took an interest in the model concept as a way to assume issue ownership in the 2010s (see Chapters 4 and 5).

Fourth, we add a cultural and commercial dimension by asking how the Nordic model has transcended the borders of the political and academic spheres and ventured into the spheres of culture, lifestyle, and advertising. This way, the Nordic label also becomes an element in branding, as a means to promote and sell products. When the 'Nordic model' is applied to new spheres, new actors and networks are involved. Since the 1930s, the Swedish model has been especially promoted and defended internationally by diplomatic actors, public intellectuals, and other interested parties, but it was not until after 2000 that aspects of both the Swedish and the Nordic models and the creative industries were promoted as brands (Chapter 4; Kharkina, 2013). The international marketing of furniture and Scandinavian design was an early example of such a development (Chapter 13; Werner, 2008; Hansen, 2018), whereas in the more recent case of New Nordic Cuisine, we 
see the mobilization of a new movement that includes entrepreneurial chefs, bureaucrats, and politicians in the respective Nordic countries (Chapter 12; Byrkjeflot et al., 2013).

\section{Theoretical perspectives}

How can we understand such processes where ideas flow and are transformed as they move into new settings and models are constructed and deconstructed over time? Here different disciplines have offered different concepts, approaches, and theories. Historical studies have witnessed an emerging 'transnational turn' over the last decade, with scholars challenging the prerogative of the national state as the 'container' of historical development (Conrad, 2011). This line of criticism has come under various labels such as 'transnational history,' 'entangled history,' or 'Histoire Croisée' (Werner and Zimmermann, 2006). Such studies have changed the analytical gaze from national contexts and institutions toward the process of movement from one context to another. Focus in this strand of research has been on things such as transnational interactions, persons and ideas traveling across national borders, translation and national domestication of imported phenomena, as well as the role of international organizations and epistemic communities.

Within the social sciences, one may refer to at least two kinds of inspirations for circulation studies: translation studies (Czarniawska and Joerges, 1996; Røvik, 2016; Rottenburg et al., 2011) and policy transfer studies (Rose, 1991; Dobbin et al., 2007; Baker and Walker, 2019). In both these fields of study, there has been a movement from more linear transfer models to a circulation approach (Stone et al., 2020). Departing from translation theory, Westney and Piekarri (2019) argue that it is not sufficient to focus on a few actors to explain the massive circulation of Japanese management concepts and practices to the West in the 1980s. Instead, they find their explanation in the 'development of an expanding translation ecosystem in which translators, translations, translation processes, and audiences interact and over time develop a "reverse flow" of models and practices.' Similarly, Djelic (2014) argues that transnational communities may, indeed, take a central role, some of them, like the neoliberal Atlas-network, are even 'born to diffuse.' In the case of 'the Nordic model,' it may not be possible to identify a single core network of translators; however, the chapters in this volume show there are international organizations and expert communities that continuously take part in the spread of models in various fields of knowledge and politics.

Both in translation and policy transfer studies, the normal way of proceeding is to focus on the diffusion (of something) from a source context to a sphere of reception. However, as observed in several chapters in this volume, it cannot be taken as a given as to what is 'origin' and what is 'audience' or 'receivers.' It is an empirical question and our circulation perspective allows 
us also to study the changing roles of actors. For example, Chapters 7, 12, and 13 (on development aid, Nordic Cuisine, and Nordic Design) show how diverse audiences outside of the Nordic region also take active part in model construction within the Nordic realm.

An important assumption in translation theory is that it matters how easily models travel and are adapted to new contexts and whether they are 'branded' with reference to their country/region of origin or not (Jaffe and Nebenzahl, 2006). The perceptions about what is a credible source may change over time and according to context. Røvik (2002: 122) suggests 'that an organizational recipe's capacity to flow depends on whether it is clearly associated with organizations or individuals that are widely recognized as authoritative actors and models.' Both Teigen (Chapter 10) and Langford/ Skilbrei (Chapter 9) argue that the success of the Nordic models they have studied relate to the reputation the Nordics have for being leaders in the field of gender equality. In the current period the Nordics seem to be attractive sources for ideas, more so now than in the early 1990 s, for instance, when the Swedish economy was in crisis.

\section{A brief outline of the book}

Our book includes case studies of how various notions of a Nordic model have circulated in international organizational, intellectual, and political circles and public spheres. The focus is on the Western world covering countries such as the United States, Spain, France, and the United Kingdom and of course the Nordic countries themselves. Combining historical, comparative, and transnational perspectives allows for a critical empirical examination of models, ideas, and images related to Nordic experiences or constructions of 'the Nordic' in transnational institutional spheres and societies outside the Nordic realm. The chapters analyze quite different types of Nordic models and policy circulations covering fields such as welfare, democracy, gender equality and gender quota, prostitution legislation, food, and furniture design. Part 1 deals with large-scale models such as 'the Swedish model,' social democratic model, welfare models, and models of scientific synthesis. This is still the predominant way of talking about the Nordic region when associated with the term model in the singular. Part 2 addresses more specific models like the development aid model, prostitution regulation model, board quotas, New Nordic cuisine, democratic design, and 'Nordic New Public Management.' In the chapters there are examples of how models have emerged and circulated in international professional networks and organizations such as among lawyers and public servants (e.g., Chapter 8 on the ombudsman), chefs (Chapter 12 on Nordic cuisine), or international organizations (Chapter 7 on development aid). Some chapters focus on specific processes of translation and transnational interaction, whereas others provide a discussion of possible effects and repercussions in the Nordic countries as well as elsewhere in the Western world (and in Chapter 7 also in Africa). 
The rich empirical findings in the individual chapters highlight the dynamic historical nature of 'the Nordic model.' They show that there has clearly been change over time in the kind of images and ideas associated with the Nordic region. This includes a diversification in what is counted as a 'Nordic model,' appropriating aspects such as regulation of prostitution, crime literature, and food. The chapters also demonstrate that these Nordic models do not have one clear origin but were sometimes developed as deliberate efforts to promote Nordic interests and at other times developed by outside observers or by academics trying to define the Model. A cacophony of actors was involved in the formulations and circulations of 'the Nordic model' - policymakers, experts, organizations, parties, states, and many more. It took place in multiple arenas and in different spheres from media debates to more closed circles and on international, national, or subnational levels - sometimes interacting, and at other times not. In other words, 'the Nordic model' has many faces and has traveled sometimes in mysterious ways. This brings us back to the underlying question, what is the Nordic model? Our answer is fairly simple: It is an empirical question that we need to answer through historical-empirical investigations. That is what the chapters in this book will do.

The editors would like to thank ReNEW and UiO:Nordic for funding research related to this book and for funding open access. The editors would also like to thank participants at workshops in Oslo 2017 and Paris 2019.

\section{References}

Andersen, L. A. and T. Björkman (2017), The Nordic Secret: A European Story of Beauty and Freedom (Stockholm: Frit Tanke Förlag).

Baker, T. and C. Walker (eds.) (2019), Public Policy Circulation: Arenas, Agents and Actions (Cheltenham: Edward Elgar Publishing).

Berghahn, V. (2010), 'The Debate on "Americanization" among Economic and Cultural Historians', Cold War History, 10(1), 107-130.

Blossing, U., G. Imsen and L. Moos (eds.) (2014), The Nordic Education Mode: 'A School for All' Encounters Neo-Liberal Policy (Dordrecht: Springer).

Blumer, H. (1954), 'What Is Wrong with Social Theory?', American Sociological Review, 19(1), 3-10.

Brandal, N., Ø. Bratberg and D. Thorsen (2013), The Nordic Model of Social Democracy (Basingstoke: Palgrave Macmillan).

Browning, C. S. (2007), 'Branding Nordicity: Models, Identity and the Decline of Exceptionalism', Cooperation and Conflict, 42(1), 27-51.

Byrkjeflot, H. (2001), 'The Nordic Model of Democracy and Management', in H. Byrkjeflot, S. Myklebust, C. Myrvang and F. Sejersted (eds.), The Democratic Challenge to Capitalism: Management and Democracy in the Nordic Countries (Bergen: Fagbokforlaget), 19-50.

Byrkjeflot, H., J. S. Pedersen and S. Svejenova (2013), 'From Label to Practice: The Process of Creating New Nordic Cuisine', Journal of Culinary Science \& Technology, 11(1), 36-55.

Castles, F. G. (ed.) (1993), Families of Nations: Patterns of Public Policy in Western Democracies (Aldershot: Dartmouth Publishing Company). 
Childs, M. (1936), Sweden; The Middle Way (New Haven, CT: Yale University Press). Christiansen, N. F., K. Petersen, N. Edling and P. Have (eds.) (2006), The Nordic Model of Welfare: A Historical Re-appraisal (Copenhagen: Museum Tusculanum). Conrad, C. (2011), 'Social Policy History after the Transnational Turn', in P. Kettunen and K. Petersen (eds.), Beyond Welfare State Models: Transnational Historical Perspectives on Social Policy (Cheltenham: Edward Elgar Publishing), 218-240.

Czarniawska, B. and B. Joerges (1996), 'Travels of Ideas', in B. Czarniawska, B. Joerges and G. Sevon (eds.), Translating Organizational Change (Berlin: Walter de Gruyter), 13-48.

Djelic, M. L. (2008), 'Sociological Studies of Diffusion: Is History Relevant?', SocioEconomic Review, 6(3), 538-557.

Djelic, M. L. (2014), 'Born to Diffuse: Towards a New Generation of Diffusion Studies?', Score Lecture in Organization 25.9.2014, available at https://www.youtube.com/watch?v=4OH_xNE0mmA [accessed March 9, 2021]

Dobbin, F., B. Simmons and G. Garrett (2007), 'The Global Diffusion of Public Policies: Social Construction, Coercion, Competition, or Learning?', Annual Review of Sociology, 33, 449-472.

Dølvik, J. E., G. J. Andersen and J. Vartiainen (2015), 'The Nordic Social Models: Consolidation and Flexible Adaptation', in J. E. Dølvik and A. Martin (eds.), European Social Models from Crisis to Crisis: Employment and Inequality in the Era of Monetary Integration (Oxford: Oxford University Press), 246-287.

Esping-Andersen, G. (1990), Three Worlds of Welfare Capitalism (Princeton, NJ: Princeton University Press).

Fellman, S., et al. (2008), Creating Nordic Capitalism (Basingstoke: Palgrave Macmillan).

Hansen, P. H. (2018), Danish Modern Furniture 1930-2016: The Rise, Decline and Re-emergence of a Cultural Market Category (Odense: Syddansk Universitetsforlag).

Hernes, H. M. (1987), Welfare State and Women Power: Essays in State Feminism (Oslo: Norwegian University Press).

Howe, F. C. (1921), Denmark: A Cooperative Commonwealth (New York: Harcourt, Brace and Company).

Hvid, H. and E. Falkum (eds.) (2018), Work and Wellbeing in the Nordic Countries: Critical Perspectives on the World's Best Working Lives (New York: Routledge).

Jaffe, E. and N. Nebenzahl (2006), National Image \& Competitive Advantage: The Theory and Practice of Place Branding, 2nd edition (Copenhagen: Copenhagen Business School).

Kettunen, P. (2011), 'The Transnational Construction of National Challenges: The Ambiguous Nordic Model of Welfare and Competitiveness', in P. Kettunen and K. Peterson (eds.), Beyond Welfare State Models: Transnational Historical Perspectives on Social Policy (Cheltenham: Edward Elgar Publishing), 16-40.

Kettunen, P. (2012), 'Reinterpreting the Historicity of the Nordic Model', Nordic Journal of Working Life Studies, 2(4), 21-43.

Kettunen, P., U. Lundberg, M. Österberg and K. Petersen (2016), 'The Nordic Model and the Rise and Fall of 'Nordic Cooperation', in J. Strang (ed.), Nordic Cooperation: A European Region in Transition (Abingdon: Routledge), 69-92.

Kharkina, A. (2013), From Kinship to Global Brand: The Discourse on Culture in Nordic Cooperation after World War II (Doctoral dissertation, Stockholm: Acta Universitatis Stockholmiensis). 
Kirkebø, T. L., M. Langford and H. Byrkjeflot (2021), 'Creating Gender Exceptionalism: The Role of Global Indexes', in E. Larsen et al. (eds.), Gender Equality and Nation Branding in the Nordic Region (London: Routledge), 191-206.

Knutsen, O. (eds.) (2017), The Nordic Models in Political Science: Challenged, But Still Viable? (Bergen: Fakbokforlaget).

Koselleck, R. (2011), 'Introduction and Prefaces to the Geschichtliche Grundbegriffe. Translated by Michaela Richter', Contributions to the History of Concepts, 6(1), 1-37.

Kuhnle, E. S. (2011), 'International Modelling in the Making of the Nordic Social Security Systems', in P. Kettunen and K. Petersen (eds.), Beyond Welfare State Models: Transnational Perspectives on Social Policy (Cheltenham: Edward Elgar Publishing), 65-81.

Lundberg, U. (2006), 'A Leap in the Dark: From a Large Actor to a Large Area Approach', in N. F. Christiansen, K. Petersen, N. Edling and P. Have (eds.), The Nordic Model of Welfare: A Historical Re-appraisal (Copenhagen: Museum Tusculanum), 269-298.

Lundqvist, ̊. (2017), Transforming Gender and Family Relations: How Active Labour Market Policies Shaped the Dual Earner Model (Cheltenham: Edward Elgar Publishing).

Lundqvist, A. and K. Petersen (eds.) (2010), In Experts We Trust: Knowledge, Politics and Bureaucracy in Nordic Welfare States (Odense: University Press of Southern Denmark).

Markkola, P. (2015), 'The Long History of Lutheranism in Scandinavia: From State Religion to the People's Church', Perichoresis, 13(2), 3-15.

Marklund, C. and K. Petersen (2013), 'Return to Sender: American Images of the Nordic Welfare State and Nordic Welfare Branding', European Journal of Scandinavian Studies, 43(2), 245-257.

Markovits, C., J. Pouchepadass and S. Subrahmanyam (eds.) (2006), Society and Circulation: Mobile People and Itinerant Cultures in South Asia, 1750-1950 (London: Anthem).

Midttun, A. and N. Witoszek (eds.) (2018), Sustainable Modernity: The Nordic Model and Beyond (New York: Routledge).

Mjøset, L. (2011), The Nordic Varieties of Capitalism (Bingley: Emerald Group Publishing Limited).

Mordhorst, M. and K. Jensen (2019), 'Co-Operatives between Stable Ideals and a Fast Changing Context', in T. D. S. Lopes, C. Lubinski and H. J. S. Tworek (eds.), The Routledge Companion to the Makers of Global Business (Abingdon: Routledge), 217-233.

Nedergaard, P. and A. Wivel (eds.) (2017), The Routledge Handbook of Scandinavian Politics (Abingdon: Routledge).

Nelson, R. H. (2017), Lutheranism and the Nordic Spirit of Social Democracy: A Different Protestant Ethic (Aarhus: Aarhus University Press).

Nygård, S. and J. Strang (2016), 'Facing Asymmetry: Nordic Intellectuals and Center-Periphery Dynamics in European Cultural Space', Journal of the History of Ideas, 77(1), 75-97.

Petersen, K. (2011), 'National, Nordic and Trans-Nordic: Transnational Perspectives on the History of the Nordic Welfare State', in P. Kettunen and K. Peterson (eds.), Beyond Welfare State Models: Transnational Historical Perspectives on Social Policy (Cheltenham: Edward Elgar Publishing), 41-64. 
Petersen, K. and K. Åmark (2006), 'Old Age and Supplementary Pensions in the Nordic Countries, 1880-2000', in N. F. Christiansen, K. Petersen, N. Edling and P. Have (eds.), The Nordic Welfare State: A Historical Re-appraisal (Copenhagen: Museum Tusculanum Press), 145-188.

Rogers, E. (1962), Diffusion of Innovations (New York: Free Press of Glencoe).

Rose, R. (1991), 'What Is Lesson-Drawing?', Journal of Public Policy, 11(1), 3-30.

Rottenburg, R., A. Behrends and S. Park (eds.) (2014), Travelling Models in African Conflict Management: Translating Technologies of Social Ordering (Leiden and Boston, MA: Brill).

Røvik, K. A. (2002), 'The Secrets of the Winners: Management Ideas that Flow', in K. Sahlin-Andersson and L. Engwall (eds.), The Expansion of Management Knowledge: Carriers, Flows and Sources (Stanford, CA: Stanford University Press), 113-144.

Røvik, K. A. (2016), 'Knowledge Transfer as Translation: Review and Elements of an Instrumental Theory', International Journal of Management Reviews, 18, 290-310.

Servan-Schreiber, J. J. (1967), The American Challenge (Paris: Denoël).

Sørensen, Ø. and B. Stråth (1997), The Cultural Construction of Norden (Oslo: Scandinavian University Press).

Stenius, H. (2010), Nordic Associational Life in a European and an Inter-Nordic Perspective (Glashütte: Nomos Verlagsgesellschaft mbH \& Co. KG), 29-86.

Stone, D., O. Porto de Oliveira and L. A. Pal (2020), 'Transnational Policy Transfer: The Circulation of Ideas, Power and Development Models', Policy and Society, 39, $1-18$.

Strang, J. (ed.) (2016), Nordic Cooperation: A European Region in Transition (London: Routledge).

von Beyme, K.(1994), 'The Significance of the Nordic Model', in S. Karlsson (ed.), The Source of Liberty, The Nordic Contribution to Europe (Copenhagen: The Nordic Council), 188-210.

Werner, J. (2008), Medelvägens estetik. Sverigebilder $i$ USA I-1l (Hedemora and Möklinta: Gidlunds förlag).

Werner, M. and B. Zimmermann (2006), 'Beyond Comparison: Histoire Croisée and the Challenge of Reflexivity', History and Theory, 45(1), 30-50.

Westney, D. E. and R. Piekkari (2019), 'Reversing the Translation Flow: Moving Organizational Practices from Japan to the U.S.', Journal of Management Studies, 57(1), 57-86.

Wiking, M. (2016), The Little Book of Hygge: The Danish Way to Live Well (London: Penguin UK). 